\title{
R\&D Efforts by Indian Pharmaceutical Firms in the New Patent Regime
}

Pulak Mishra *

Abstract:

In the context of recent amendments to the Indian Patent Act and introduction of the product patent, the present paper attempts to examine the innovative efforts of Indian pharmaceutical companies in the new patent regime. The paper finds that although $R \& D$ expenditure has increased significantly in the current decade, the increasing R\&D efforts are not widespread across the firms and more than half of the Indian pharmaceutical companies do not spend at all on in-house R\&D. This means that protection of intellectual property alone is not enough to encourage the firms towards innovation. Instead, it is observed that $R \& D$ expenditure varies directly the with market size of the firms, their capital intensity, exports orientation and past profitability, but inversely with their market share, selling efforts and import intensity. However, a firm's involvement in mergers and acquisition or sourcing of technology from foreign sources or variability in financial performance does not have any significant impact on its R\&D efforts. Hence, the policy measures should be directed towards restricting the monopoly power of firms, encouraging exports, liberalizing imports of necessary machinery and equipment, and motivating the firms towards innovation, especially in life-saving drugs, an through appropriate incentive/disincentive structure.

Keywords: R\&D, Technology, Competition, Patent, Policy

JEL: D21, D4, L1, L2

DOI: 10.2478/v10033-010-0018-z

\section{Introduction}

India's obligation to sign the TRIPS agreement in 1994 to become a member of WTO in 1995 has been followed by three important amendments to the Indian Patent Act (1970), viz., the Patent First Amendment Act in 1999, Patent (Second Amendment) Bill in 2002 and Patent (Amendment) Bill in 2005. On the one hand, implementation of TRIPS has put restrictions on the production of generic drugs and has opened up investment opportunities for R\&D of new molecules (Janodia, et al., 2009). On the other hand, the amendments to the Indian Patent Act have made a

\section{*Pulak Mishra}

Indian Institute of Technology Kharagpur, Kharagpur - 721 302, India

E-mail:pmishra@hss.iitkgp.ernet.in marked shift from the process patent regime towards an era of the product patent. While the first amendment in 1999 introduced the mailbox provisions to receive product patent applications, the second amendment in 2002 extended the term of a patent to 20 years. The amendment in 2005, on the other hand, finally recognized the WTO mandated product patent ${ }^{1}$ provision. In addition, the Pharmaceutical Policy (2006) also aims at promoting R\&D in the industry by creating an appropriate incentive structure ${ }^{2}$.

${ }^{1}$ This introduction of product patent regime is expected to have a significant impact on market concentration, prices of drugs and performance of the industry.

${ }^{2}$ For a discussion in this regard, see Ray (2008). 
The existing patent laws are expected to provide greater market power to the firms as an incentive to innovate. But, can the new patent regime necessarily make the firms more innovative, particularly when innovative efforts by the firms have their own set of costs and uncertainties? Further, in addition to patent laws, a firm's decision to invest in innovation may be determined by structural aspects of the market and the firm's relative position therein, alternative strategic options available to the firm, and its ability to invest in R\&D. For example, when there are imperfections in the capital market, only the larger firms with stability and internally generated funds can afford to invest in risky R\&D. Similarly, when the innovating firms have a larger market, the returns from $R \& D$ are also likely to be higher due to the spread of fixed costs of R\&D over a large volume of sales. In addition, some other firm-specific characteristics like financial performance, degree of product diversification, export orientation, and import intensity can also influence the $R \& D$ decisions of firms ${ }^{3}$.

In this context, the present paper makes an attempt to examine the innovative efforts of Indian pharmaceutical firms in the new patent regime. The rationale for such attempt lies in the role of R\&D in the growth and survival of a firm, particularly in a research intensive industry like pharmaceuticals. The firms with greater innovative efforts experience higher growth rates and also have higher chances of survival (Hall 1987; Doms et al., 1995). With the pharmaceutical industry being technology intensive, enhancing competitiveness is crucial for growth and survival of firms. On the other hand, in-house R\&D fails to provide any distinct advantage to firms in terms of their profitability (Mishra and Chandra, 2010) and this may largely be because of their low R\&D intensity vis-à-vis the pharmaceutical companies of the industrially developed countries operating in India. In addition, the developing countries may lose by granting patent protection when the costs of patent protection outweigh its benefits (Penrose, 1951; Vaitsos, 1972; Greer, 1973). Developing countries may also suffer from higher prices resulting from patent monopolies. The rest of the paper is divided into three sections. Section II discusses the recent trends in R\&D efforts vis-à-vis other technology strategies in the Indian pharmaceutical industry. Section attempts III to identify the factors that influence the R\&D efforts of firms. Section IV concludes the paper with necessary policy suggestions.

${ }^{3}$ For a review on the determinants of R\&D, see Pradhan (2003), Bhattacharya and Bloch (2004).
2. Technology Strategies of Indian Pharmaceutical firms

The nature and extent of innovative efforts of firms in the Indian pharmaceutical industry have changed considerably since the mid-1990s. Not only has the amount of $R \& D$ expenditure in the industry increased substantially (Pradhan, 2003; Chaudhuri, 2007), the structure of R\&D activities by the Indian companies has also changed from development of new processes to modifications of existing drugs as well as development of new formulations and compositions (Chaudhuri, 2007). R\&D expenses have increased at a higher rate of 5.07 percent in the post-TRIPs period as compared to the rate of growth of 3.88 percent in the pre-TRIPS period (Kiran and Mishra, 2009). The industry has become one of the two most important spenders on innovation, the other being the automotive sector. Currently India's national system of innovation is largely dominated by this industry (Mani, 2009). In addition, patenting by the Indian pharmaceutical companies has also gone up significantly over the years (Chaudhuri, 2007) ${ }^{4}$.

The increase of innovative efforts by the pharmaceutical companies seem to have contributed significantly to the rapid growth of the industry ${ }^{5}$. Today, the industry ranks fourth globally in terms of volume and thirteenth in terms of value. Further, while traditionally the industry used to be dominated by MNCs, currently, a number of Indian companies are dominating the market along with many of the key therapeutic segments. Some of the Indian pharmaceutical companies like Ranbaxy Industries, Dr. Reddy's Laboratories, Wockhardt, Cipla, Nicholas Piramal and Lupin have created a strong presence even in developed markets such as the US and Europe.

However, when these innovative activities are considered vis-à-vis other technology strategies, it is observed that expenditure on technology purchase, especially from foreign sources, has also increased along with in-house $R \& D$, while the rate of increase in $R \& D$ intensity is only marginally higher than that for foreign technology purchase intensity between 2001 and 2008 (Table 1). When the negative rate of growth of technology purchase intensity during 1996-2000 is

${ }^{4}$ However, the growth in R\&D by the larger firms is expected to be greater than that for the industry as a whole as the larger firms have the necessary resources to invest in $R \& D$.

${ }^{5}$ The other factors contributing to this rapid growth of the industry may include low cost advantage and availability of skilled manpower. 


\begin{tabular}{|l|l|c|c|c|c|c|}
\hline \multicolumn{2}{|l|}{ Technology Strategy } & AVG & CV & $\begin{array}{c}\text { TGR (\%) } \\
(\mathbf{1 9 9 6 - 2 0 0 0 )}\end{array}$ & $\begin{array}{c}\text { TGR (\%) } \\
(\mathbf{2 0 0 1 - 2 0 0 8 )}\end{array}$ & $\begin{array}{c}\text { TGR \% } \\
\text { (1996-2008) }\end{array}$ \\
\hline \multirow{3}{*}{$\begin{array}{l}\text { Technology } \\
\text { Purchase Intensity }\end{array}$} & Domestic & 0.09 & 0.41 & 3.75 & -4.06 & -9.07 \\
\cline { 2 - 7 } & Foreign & 1.21 & 0.38 & -21.81 & 14.67 & 13.61 \\
\cline { 2 - 7 } & Total & 1.31 & 0.34 & -18.48 & 15.35 & 4.60 \\
\hline \multicolumn{2}{|l|}{ In-house R\&D Intensity } & 2.96 & 0.58 & 2.26 & 14.75 \\
\hline
\end{tabular}

Note: AVG - Average, CV - Coefficient of Variation, TGR - Trend Growth Rate Source: Prowess Database, CMIE.

Table 1: Alternative Technology Strategies of Pharmaceutical Companies

\begin{tabular}{|l|c|c|c|c|c|c|}
\hline \multirow{2}{*}{ R\&D Intensity (\%) } & \multicolumn{2}{|c|}{$2000-01$} & \multicolumn{2}{|c|}{$2004-05$} & \multicolumn{2}{c|}{$2007-08$} \\
\cline { 2 - 7 } & $\begin{array}{c}\text { No. of } \\
\text { Firms }\end{array}$ & $\begin{array}{c}\text { Share in Total } \\
(\%)\end{array}$ & $\begin{array}{c}\text { No. of } \\
\text { Firms }\end{array}$ & $\begin{array}{c}\text { Share in Total } \\
\text { (\%) }\end{array}$ & $\begin{array}{c}\text { No. of } \\
\text { Firms }\end{array}$ & $\begin{array}{c}\text { Share in } \\
\text { Total (\%) }\end{array}$ \\
\hline $\mathrm{RI}=0$ & 169 & 64.0 & 181 & 60.1 & 120 & 56.6 \\
\hline $0<\mathrm{RI}<1$ & 40 & 15.2 & 33 & 11.0 & 22 & 10.4 \\
\hline $1<\mathrm{Rl}<2$ & 17 & 6.4 & 32 & 10.6 & 15 & 7.1 \\
\hline $2<\mathrm{Rl}<5$ & 21 & 8.0 & 22 & 7.3 & 20 & 9.4 \\
\hline $5<\mathrm{Rl}<10$ & 11 & 4.2 & 13 & 4.3 & 17 & 8.0 \\
\hline$\geq 10$ & 6 & 2.3 & 20 & 6.6 & 18 & 8.5 \\
\hline & 264 & 100.0 & 301 & 100.0 & 212 & 100.0 \\
\hline
\end{tabular}

Source: Prowess Database, CMIE.

Table 2

considered, the acceleration appears to be even much higher in the case of technology purchase. In addition, fluctuation in in-house R\&D intensity is also much higher as compared to that of technology purchase intensity, indicating lack of consistency in R\&D efforts by firms.

Besides, the distribution of firms has considerably shifted towards higher R\&D intensity between 2000 and 2001 and 2007 and 2008 (Table 2). This means that the proportion of firms spending a larger part of their sales on $R \& D$ has increased over the years. Yet more than half of the firms still don't spend at all on innovation and around two-thirds spend even less than 2 percent of their sales for this purpose. This means that greater innovative efforts following amendments to the Indian Patent Act are not widespread across firms in the Indian pharmaceutical Industry.

When viewed at the firm level, we find that many of the market leaders like Sun Pharmaceuticals, Dr. Reddy's Laboratories, Ranbaxy, Wockhardt spend a considerable portion of their sales on innovation and their R\&D intensity has increased over the years (Table 3). At the same time, some of the leading firms like Glaxosmithkline Pharmaceuticals, and Novartis India spend only a very small part of their sales on R\&D. In other words, the R\&D intensity of the firms does not show any significant increase across firms in the new IPR regime. The R\&D intensity of some firms such as Ajanta Pharmaceuticals,
Piramal Healthcare, and Abbott India has also fluctuated over the years.

Thus, although it increased considerably in recent years, the R\&D intensity of Indian pharmaceutical firms has fluctuated considerably both at the industry and firm levels. Further, the acceleration is confined largely to a set of leading firms in the industry and more than half of the firms rely completely on technology sourcing from outside to enhance their competitive strength. This is clearly evident from the fact that technology purchase intensity, especially from foreign sources, has increased considerably during the present decade ${ }^{6}$.

This means that the new TRIPS-compliant product patent regime in India may not be the primary incentive to invest in in-house $R \& D^{7}$. Instead, the increasing $R \& D$ efforts in the industry may be contributing to the anticipated shrinkage of domestic opportunities due to the existing product patent regime in developed countries well before TRIPS (Chaudhuri, 2007). Many of the leading firms in the industry have used the routes of mergers and acquisitions (M\&A) to strengthen their R\&D

\footnotetext{
${ }^{6}$ However, in some cases, the rapid increase in technology purchase intensity may be due to complementarities with indigenous technology. ${ }^{7}$ Strong patent protection has traditionally been seen as unnecessary until relatively late in a country's development process. Developing countries are net users, not net developers of R\&D intensive products (Siebeck, 1990).
} 


\begin{tabular}{|c|c|c|c|}
\hline \multirow{2}{*}{ Company } & \multicolumn{3}{|c|}{ R\&D Intensity (\%) } \\
\hline & 2000-01 & 2004-05 & 2007-08 \\
\hline Sun Pharmaceutical Industries Ltd. & 4.47 & 11.11 & 31.07 \\
\hline Dr. Reddy's Laboratories Ltd. & 4.22 & 18.32 & 14.31 \\
\hline Wockhardt Ltd. & 9.46 & 10.14 & 16.13 \\
\hline Ajanta Pharmaceuticals Ltd. & 22.41 & 0.42 & 10.77 \\
\hline Ranbaxy Laboratories Ltd. & 4.89 & 12.28 & 14.88 \\
\hline Torrent Pharmaceuticals Ltd. & 5.72 & 13.08 & 11.79 \\
\hline Cadila Healthcare Ltd. & 8.67 & 10.94 & 9.58 \\
\hline Venus Remedies Ltd. & 4.02 & 10.77 & 12.38 \\
\hline Glenmark Pharmaceuticals Ltd. & 12.67 & 9.09 & 4.70 \\
\hline Lupin Ltd. & 5.49 & 7.28 & 8.64 \\
\hline Piramal Healthcare Ltd. & 2.33 & 12.48 & 2.32 \\
\hline Cipla Ltd. & 3.91 & 4.23 & 6.68 \\
\hline Abbott India Ltd. & 0.97 & 9.69 & 3.20 \\
\hline Aurobindo Pharmaceuticals Ltd. & 1.04 & 4.78 & 5.06 \\
\hline Novartis India Ltd. & 3.12 & 1.23 & 1.00 \\
\hline Glaxosmithkline Pharmaceuticals Ltd. & 0.70 & 0.53 & 0.36 \\
\hline
\end{tabular}

Source: Prowess Database, CMIE.

Table 3: Innovative Efforts of the Leading Pharmaceutical Companies

base (Mishra, 2006). In addition, strategic alliances or tieups, and foreign direction investment (FDI) in the industry are also likely to provide the firms access to better technology and thereby to restrict the firms from investing in in-house R\&D. A deeper understanding of the firms' response in the new patent regime, therefore, requires identification of the factors that influence their R\&D efforts. The next Section of the paper is an attempt in this direction.

\section{Determinants of R\&D Efforts}

\subsection{Specification of Functional Relationship}

The factors that determine the R\&D efforts by the pharmaceutical firms can be identified by using the structure-conduct-performance (SCP) framework based on the early work of Edward Mason (1939) and developed further by Bain (1959) ${ }^{8}$. While the traditional SCP paradigm

${ }^{8}$ The original SCP framework is criticised on the grounds that the analyses are purely empirical in nature and they lack rigorous foundation in economic theory (Davies et al., 1989). Besides, the model is too deterministic to understand the functioning of imperfect markets (Scherer and Ross, 1990). However, the extensive application of the framework to different industries under various economic environments and apparent success of the approach has led to a more robust theory of industrial organisation. postulates a unidirectional relationship from structure to conduct and from conduct to performance, successive developments in the industrial organization literature suggest multidimensional causal relationships amongst market structure, firms' conduct, their performances and policies of the government ${ }^{9}$. Considering that in-house $R \& D$ is an important instance of firm conduct, we hypothesize that R\&D efforts by a firm (R\&D) depend on market conditions (MST), and conduct other than R\&D $(\mathrm{FCN})$ and performance (PER), i.e.,

$$
R \& D=f(M S T, F C N, P E R)
$$

Let us include market demand (MSZ) and market share (SHARE) as proxies for market conditions, mergers and acquisitions (M\&A), capital intensity (KI), selling efforts (SELL), exports intensity (EXP), imports intensity of finished products (IMP) and foreign technology purchase intensity (FTPI) for firms' conduct other than R\&D, and profitability (PROF) and firm-level risks (FR) for firms' performance. The above functional relationship can, therefore, be rewritten as:

$$
\begin{gathered}
R \& D=f(M S Z, S H A R E, M \& A, K I, F T P I, S E L L, \\
E X P, I M P, P R O F, F R)
\end{gathered}
$$

\footnotetext{
${ }^{9}$ See, Scherer and Ross (1990) for the details in this regard.
} 
As the influence of M\&A, FTPI, SELL, PROF and FR on R\&D may not be instantaneous and many of these independent variables like FTPI, PROF, SELL may be influenced by R\&D as well, following (Kambhampati, 1996) we introduce a one-year lag in these variables to capture the dynamics of adjustments as well as to control for the problem of endogeneity ${ }^{10}$. Hence, we rewrite (2) as the following:

$$
\begin{aligned}
& R \& D_{i t}=f\left(M S Z_{i t}, S H A R E_{i t}, M \& A_{i, t-1}, K I_{i t},\right. \\
& \left.F T P I_{i, t-1}, S E L L_{i, t-1}, E X P_{i t}, I M P_{i t}, P R O F_{i, t-1}, F R_{i, t-1}\right)
\end{aligned}
$$

It should be mentioned that there is no consensus on the measurement of firms' innovative efforts in the literature. A number of indices, such as expenditure on $R \& D$, number of persons engaged in R\&D activities, number of invention patents received, extent of significant innovation pioneered, estimates of sales associated with new products, etc. are used in the existing studies for measuring firms' innovation efforts (Bhattacharya and Bloch, 2004). The choice of measure depends largely on convenience and the logical judgment of the researchers ${ }^{11}$. However, as data on $R \& D$ expenditure are easily available at the firm level, in the present paper, we use R\&D intensity, i.e., the ratio of $R \& D$ expenditure to sales as a measure of firms' $R \& D$ efforts.

\subsection{Probable Impact of the Explanatory Variables}

MSZ: The larger a market a firm has the greater its willingness and ability to spend more on innovation. It also encourages the entry of new firms and the consequent competitive pressure forces the existing firms to enhance their efficiency and competitiveness through R\&D. Having a larger market may also induce a firm to create a strategic entry barrier through $R \& D$. In other words, a larger market is expected to result in greater $R \& D$ efforts.

SHARE: A large number of studies (e.g. Scherer, 1967; Gilbert and Newbery, 1982) suggest that dominant firms tend to have greater R\&D efforts. Firms with higher market share are likely to have greater ability and willingness to spend for innovation due to their 'deep

\footnotetext{
${ }^{10}$ The $R \& D$ behaviour of firms is a complex phenomenon and the lines of causation often run from supposed determinants to $R \& D$ and from $R \& D$ to its supposed determinants (Pradhan, 2003). For example, while foreign technology purchase may depend on initial indigenous technological capabilities (Katrak, 1997), high profit margin may itself be an outcome of successful R\&D activities (Kumar and Saqib, 1996).

${ }^{11}$ For the details on problems of measuring innovation, see Kuznets (1962).
}

pockets' and expected higher market power. However, the larger market share of a firm can also make it complacent and hence reduce its urge to innovate. The nature of relationship between market share and $R \& D$ intensity of a firm, therefore, depends on which of these processes dominates empirically.

M\&A: It is observed that the foreign affiliates spend significantly less on $R \& D$ than their domestic counterparts in the Indian manufacturing sector (Kumar, 1987; Kumar and Saqib, 1996; Kumar and Agarwal, 2000) as they have access to the R\&D base of the parent companies. When a domestic firm is acquired by or merged with a foreign affiliate, it gets easy access to better technology and R\&D base. This is likely to reduce the in-house R\&D efforts of the domestic firm. On the other hand, if M\&A by domestic firms raise their market power, R\&D efforts may increase. Further, some of the M\&A in the industry were guided by the motive of strengthening R\&D bases (Mishra, 2006). Thus, the nature of the impact of M\&A on the R\&D efforts of a firm depends on the relative strength of these diverse forces.

KI: A firm with high capital intensity deters entry and, therefore, reduces possible competitive threat. This may encourage the firm towards in-house R\&D. However, when a firm sources technologies in embodied form (e.g., machines, tools, equipments, etc.) the necessity of inhouse $R \& D$ efforts declines. Thus, the nature of the impact of $\mathrm{KI}$ on the R\&D efforts of a firm depends on the relative strength of these diverse forces.

FTPI: A number of studies have examined the relationship between technology imports and R\&D expenditure (e.g., Katrak, 1991; Siddharthan and Krishna, 1994; Basant, 1997) and it is often found to be a complex one (Kumar, 1987). Many of the firms source technologies in disembodied form from abroad due to their limited capabilities towards the development of indigenous technologies. In such cases, the purchase of foreign technology is a substitute for R\&D activity in the receiving firms. On the other hand, if in-house R\&D is adaptive in nature, a complementary relationship can be postulated. The exact nature of the relationship between R\&D and FTPI, therefore, depends on the requirement of the firms and the nature of R\&D.

SELL: Production differentiation and the creation of entry barriers through advertising are treated as strategic alternatives to innovation by firms. Further, in the absence of in-house $R \& D$, creation of marketing and distribution related complementary assets can also provide adequate competitive advantage to the firms. 
Therefore, the firms that spend more on advertising, marketing and distribution, may be expected to spend less on in-house R\&D.

EXP: Survival in the international market requires greater competitiveness, especially, in terms of offering new quality products at lower prices vis-à-vis competitors. Greater penetration in the international market can also raise the ability of firms to spend on innovation. Hence, the firms with greater outward orientation through exports are likely to spend more on innovation (Braga and Willmore, 1991; Kumar and Saqib, 1996; Kumar and Agarwal, 2000).

IMP: Assuming that imported drugs and pharmaceutical products are of better quality, one may expect that the firms with higher import intensity to have greater dominance over the market at a quicker interval. When this is the case, greater import intensity may reduce the $R \& D$ efforts of the firms concerned. However, greater import competition may also force the firms to be more innovative (Bhattacharya and Bloch, 2004).

PROF: Firms with better financial performance are expected to have greater ability as well as willingness to spend on innovation (Branch, 1974; Grabowski, 1986; Audretsch, 1995). It is also possible that firms with better financial performance may become complacent and reduce their emphasis on innovation. On the other hand, firms with low profitability may be under pressure to be innovative to become more competitive (Horowitz, 1961; Braga and Willmore, 1991). The impact of profitability on $R \& D$ intensity, therefore, depends on which of the diverse forces dominates.

FR: High firm-level risks, conventionally measured in terms of the variability in the firm's performance over time, may compel a firm to make R\&D efforts to stabilize its performance, especially when the variability is due to increasing inter-firm competition. High firm-level risks may also make in-house $R \& D$ a risky proposition and hence force the firm to rely on technology sourcing and other strategic alternatives to enhance competitiveness.

\subsection{Methodology and Data}

The above regression equation is estimated by applying panel data estimation techniques for a set of 52 listed drugs and pharmaceutical companies over the period between 2000 to 2001 and 2007 to 2008. Use of panel data helps in raising the sample size and hence the degrees of freedom considerably. It also incorporates the dynamics of firms' behavior in the marketplace. This is very important in having a better understanding of the factors that influence firms' R\&D decisions. Necessary data are collected from the PROWESS database of the Centre for Monitoring the Indian Economy (CMIE), Mumbai. Here, all the variables are measured as simple three years' averages from the year under reference to make the data set more consistent over time. Further, such measures of the variables along with a one-year lag in the functional model take care of the adjustment process for the variables and eliminate the problem of simultaneity. Details on the measurement of the independent variables are given in Appendix I.

We estimate the random effects model (REM). The choice of REM over the fixed effects model (FEM) is based on the assumption made on the intercept. It is assumed that the intercept is a random variable with a common population mean and the firm specific intercept differs from the population mean by the error term. This is so because the sample firms in the present paper are drawn from a very large population ${ }^{12}$ and, therefore, the individual effect is likely to be random ${ }^{13}$. Further, each of the firms in the industry may have a large number of decisional/strategic options. Therefore, even when we control for the determinants of a firm's R\&D decisions, this may not be exhaustive, ${ }^{14}$ causing firm specific intercepts to be random. Hence, the above functional relationship can be rewritten as the following:

$$
\begin{aligned}
R \& D_{i t}= & \alpha_{1 i}+\alpha_{2} M_{S Z_{i t}}+\alpha_{3} \operatorname{SHARE}_{i t}+\alpha_{4} M \& A_{i, t-1}+ \\
& +\alpha_{5} \text { II }_{i}+\alpha_{6} \text { FTPI }_{i, t-1}+\alpha_{7} S E L L_{i, t-1}+ \\
& +\alpha_{8} E X P_{i}+\alpha_{9} I M P_{i}+\alpha_{10} \text { PROF }_{i, t-1}+ \\
& +\alpha_{11} F R_{i, t-1}+u_{i t}
\end{aligned}
$$

Here, $\alpha_{1 i}=\alpha_{1}+\varepsilon_{i}$

This means that the intercept is a random variable with a common mean $\alpha_{1}$ and the firm specific intercept differs from the population mean by the error term $\varepsilon_{i}$. As

\footnotetext{
${ }^{12}$ By large population we refer not only to infinite individual units but also to the infinite number of decisions that each firm may take.

${ }^{13}$ In the present paper, we consider a set of 52 pharmaceutical firms, which is only a small part of the much universe of the Indian pharmaceutical industry.

${ }^{14}$ In fact, R\&D decisions may be influenced by a large number of other factors in addition to those considered in the present model. This may include cost of innovation, uncertainty in innovation outcome, experience of the firm in in-house $R \& D$, nature and structure of its ownership, etc. However, due to lack of systemic data, the present paper fails to capture this aspect.
} 
mentioned above, the rationale behind such assumption is that when ' $n$ ' cross sectional units are drawn from a relatively large population, the individual effect is characterized as random and inference pertains to the population from which the sample is drawn. This causes heterogeneities in firm-specific intercepts that are reflected in the error term $\varepsilon_{\mathrm{j}}$. Substituting (5) in (4) we get,

$$
\begin{aligned}
R \& D_{i t} & =\alpha_{1}+\alpha_{2} M_{S Z_{i t}}+\alpha_{3} S H A R E_{i t}+ \\
& +\alpha_{4} M \& A_{i, t-1}+\alpha_{5} K I_{i}+\alpha_{6} F T P I_{i, t-1}+ \\
& +\alpha_{7} S E L L_{i, t-1}+\alpha_{8} E X P_{i}+\alpha_{9} I M P_{i}+ \\
& +\alpha_{10} \text { PROF }_{i, t-1}+\alpha_{11} F R_{i, t-1}+\omega_{i t}
\end{aligned}
$$

Here, $\omega_{i t}=\varepsilon_{i}+u_{i t}$

In other words, the composite error term of equation (6) consists of cross-section specific error $\left(\varepsilon_{i}\right)$ as well as the combined time-series and cross-section error component $\left(u_{i t}\right)$. It is assumed that the errors follow normal distribution with zero mean and constant variance, i.e., $\varepsilon_{i} \sim N\left(0, \sigma^{2}{ }_{\varepsilon}\right)$ and $u_{i t} \sim N\left(0, \sigma^{2}{ }_{u}\right)$. It is also assumed that the individual error components are not correlated with each other and are not autocorrelated across both cross-section and time-series units, i.e., $E\left(\varepsilon_{i} u_{i t}\right)=E\left(\varepsilon_{i} \varepsilon_{j}\right)=0(i \neq j)$ and $E\left(u_{i t} u_{i s}\right)=E\left(u_{i t} u_{j t}\right)=E\left(u_{i t} u_{j s}\right)=0(i \neq j ; t \neq s)$.

Therefore, $E\left(\omega_{i t}\right)=0$ and $\operatorname{Var}\left(\omega_{i t}\right)=\sigma^{2}{ }_{\varepsilon}+\sigma^{2}{ }_{u}$. This makes the composite error terms of a given crosssectional unit at two different time points correlated ${ }^{15}$ and for any given cross sectional unit the value of this correlation coefficient remains the same even if the two time points are distinctly away from each other. Further, the correlation coefficient also remains the same for all the individual units. When it is so, estimation of equation (7) by the method of ordinary least squares will result in inefficient estimators. So, following Gujarati and Sangeetha (2007), in the present paper, equation (7) is estimated by applying the method of feasible generalized least squares $(\mathrm{FGLS})^{16}$.

\footnotetext{
${ }^{15}$ The correlation coefficient of the composite error term for firms $i$ at time point $t$ and $s, \operatorname{corr}\left(\omega_{i t}, \omega_{i s}\right)=\frac{\sigma_{\varepsilon}^{2}}{\sigma_{\varepsilon}^{2}+\sigma_{u}^{2}}(t \neq s)$.

${ }^{16}$ In FGLS, first the method of OLS is used to derive an estimator of the covariance matrix of the error term and then this covariance structure is used to estimate the coefficients.
}

There are two distinct advantages of applying REM over FEM. First, while the observed characteristics that remain constant for each individual are dropped in FEM, they are retained in REM. Second, unlike the FEM, the REM does not lose degrees of freedom to estimate cross-sectional intercepts. The assumption of randomness vis-à-vis pooled regression is confirmed by using the Breusch and Pagan (1980) Lagrange Multiplier test. The Breusch-Pagan Lagrange Multiplier Test examines the validity of the REM on the basis of the null hypothesis that the variance of the random disturbance term is zero, i.e., $H_{o}: \sigma_{u}{ }^{2}=0$ against the alternative hypothesis that the variance of the random disturbance term is different from zero, i.e., $H_{1}: \sigma_{u}{ }^{2} \neq 0$

The test uses the following test-statistic that follows $\chi^{2}$ distribution:

$L M=\frac{n T}{2(n-1)}\left[\frac{\sum n \bar{\varepsilon}_{t}{ }^{2}}{\sum \sum \varepsilon_{i t}{ }^{2}}-1\right]^{2} \sim \chi^{2}(1)$

Here, $\mathrm{T}$ is number of time periods; $\mathrm{n}$ number of groups of states. If the computed $\chi^{2}$ is less than the critical value, i.e., if the null hypothesis is not rejected, the pooled regression model is appropriate. When the computed $\chi^{2}$ that exceeds the critical value, we reject the null hypothesis in favor of the REM and confirm random effects in the relationships.

\subsection{Results and Discussions}

The summary statistics of the variables used in the regression model are presented in Table 4. The regression results of the pooled regression model and the REM are given in Table 5 . It is observed that the F-statistic in the pooled regression model and the Wald $\chi^{2}$ statistic in the REM are statistically significant. Further, the value of $R^{2}$ is also quite high in both models. This means that both the estimated models are statistically significant with high explanatory power. However, as the Breusch-Pagan $\chi^{2}$ is statically significant, the REM is preferred to the pooled regression model. Accordingly, the regression results of the REM are used to discuss the individual coefficients.

It is observed that the coefficients of MSZ, SHARE, Kl, SELL, PBIT, EXP and IMP are statistically significant. While MSZ, EXP, KI and PBIT have significant positive impact on R\&D intensity, SHARE, SELL and IMP have significant negative impact on the same. This means that the firms with higher demand in the domestic market or greater penetration in the international market, greater capital 


\begin{tabular}{|c|c|c|c|c|c|}
\hline Variable & Observation & Mean & Standard Deviation & Minimum & Maximum \\
\hline $\mathrm{RD}$ & 260 & 3.06 & 5.05 & 0.00 & 37.82 \\
\hline MSZ & 260 & 4.38 & 2.35 & -1.92 & 8.06 \\
\hline SHARE & 260 & 1.92 & 2.94 & Neg. & 16.20 \\
\hline MA & 260 & 0.78 & 1.25 & 0.00 & 7.00 \\
\hline $\mathrm{KI}$ & 260 & 1.67 & 3.05 & 0.26 & 28.21 \\
\hline FTPI & 260 & 0.15 & 0.97 & 0.00 & 13.27 \\
\hline SELL & 260 & 14.71 & 32.75 & 0.00 & 354.48 \\
\hline EXP & 260 & 21.54 & 25.62 & 0.00 & 123.97 \\
\hline IMP & 260 & 20.86 & 47.96 & 0.00 & 457.78 \\
\hline PBIT & 260 & 30.36 & 103.58 & -166.53 & 1212.57 \\
\hline FR & 260 & 16.60 & 66.47 & 0.06 & 737.42 \\
\hline
\end{tabular}

Note: Neg. -Negligible $(<0.005)$.

Table 4: Summary Statistics of the Variables used in the Regression Model

intensity or better financial performance have higher R\&D intensity. Larger presence in the domestic or international market ${ }^{17}$ or better financial performance boosts a firm's innovation intensity. Better financial performance also raises a firm's ability for R\&D, whereas higher capital intensity encourages a firm towards innovation by creating an entry barrier.

On the other hand, firms with greater share in the domestic market or with greater selling efforts or higher import intensity spend less on in-house R\&D. In other words, Indian pharmaceutical companies use product differentiation through advertising, creation of marketing and distribution of related complementary assets and import of drugs and pharmaceutical products $^{18}$ as alternative strategies to innovation. Besides, a relatively strong position in the market makes a firm complacent and reduces its innovative efforts. This is contradictory to the findings of a large number of studies (e.g. Scherer, 1967; Gilbert and Newbery, 1982) which suggest that dominant firms tend to have greater R\&D efforts.

Interestingly, the coefficients of M\&A, FTPI and FR are not statistically significant. This means that mergers and acquisitions or foreign technology purchase or variations in firms' profitability do not have significant impact on the R\&D efforts of Indian pharmaceutical companies. There are three interesting aspects to these findings. First,

\footnotetext{
${ }^{17} \mathrm{~A}$ positive coefficient of exports intensity is consistent with the findings of Braga and Willmore (1991), Kumar and Saqib (1996), Kumar and Agarwal (2000), Bhattacharya and Bloch (2004).

${ }^{18} \mathrm{~A}$ negative coefficient of import intensity is contradictory to the findings of Bhattacharya and Bloch (2004). This may be due to greater dominance by the firms over the market in a quicker interval though imports of quality drugs and pharmaceutical products and hence lower intention to innovate.
}

no statistically significant impact of FTPI on R\&D intensity suggests that foreign technologies are neither substitutes nor complements of in-house innovation in the Indian pharmaceutical industry. This is contradictory to the findings of many of the earlier studies (e.g., Lall, 1983; Katrak, 1990; Basant, 1997; Kumar and Agarwal, 2000) that indicate a complementary relationship between imports of foreign technology and R\&D activity of domestic firms in Indian manufacturing.

Second, more number of M\&A by a firm neither increases its R\&D intensity nor reduces the same. Increase in market power though M\&A may encourage a firm towards innovation, but if it has easy access to better technology of the participating firm(s), R\&D efforts may not be enhanced. The observation of no statistically significant impact of M\&A on R\&D intensity, therefore, suggests that while many of the Indian firms use the route of M\&A to strengthen their R\&D base (Mishra, 2006), others largely rely on the R\&D base of their foreign affiliates. One may expect M\&A to increase market power of the domestic firms and hence their R\&D efforts. However, this possibility is ruled out in the present context as market share has an inverse relationship to R\&D intensity.

Third, Indian pharmaceutical firms make decisions on spending for R\&D on the basis of the level of profitability not on the basis of its variability. The observation of a positive relationship between profitability and R\&D intensity is consistent with the findings of Branch (1974), Grabowski (1986), and Audretsch (1995). However, the firms with greater fluctuations in their profitability do not use innovation as a route to stabilize financial performance nor do they reduce R\&D efforts to avoid 


\begin{tabular}{|c|c|c|c|c|c|}
\hline \multicolumn{3}{|c|}{ Pooled Regression } & \multicolumn{3}{|c|}{ Random Effects Model } \\
\hline Variable & Coefficient & t-Statistic & Variable & Coefficient & z-Statistic \\
\hline Intercept & -3.069 & $-3.74^{*}$ & Intercept & -3.658 & $-3.88^{*}$ \\
\hline MSZ & 0.624 & $3.70^{*}$ & MSZ & 0.956 & $3.88^{*}$ \\
\hline SHARE & 0.214 & 1.30 & SHARE & -0.499 & $-2.05^{* *}$ \\
\hline$M \& A$ & 0.924 & $2.88^{*}$ & $M \& A$ & 0.064 & 0.28 \\
\hline $\mathrm{KI}$ & 0.972 & $2.56^{* *}$ & $\mathrm{KI}$ & 0.670 & $2.55^{* *}$ \\
\hline FTPI & -0.112 & -0.80 & FTPI & -0.001 & -0.01 \\
\hline SELL & -0.047 & $-2.18^{* *}$ & SELL & -0.043 & $-1.90^{* * *}$ \\
\hline EXP & 0.058 & $3.67^{*}$ & EXP & 0.131 & $4.37^{*}$ \\
\hline IMP & -0.007 & $-2.57^{* *}$ & IMP & -0.015 & $-3.17^{*}$ \\
\hline PROF & 0.011 & 1.65 & PROF & 0.014 & $2.16^{* *}$ \\
\hline FR & -0.006 & -0.80 & $\mathrm{FR}$ & 0.002 & 0.38 \\
\hline F-Statistic & $156.73^{*}$ & & Wald $\chi^{2}$ & $4284.4^{*}$ & \\
\hline $\mathrm{R}^{2}$ & 0.64 & & $\mathrm{R}^{2}$ - Within & 0.68 & \\
\hline \multirow[t]{4}{*}{ No. of observations } & 260 & & $\mathrm{R}^{2}$ - Between & 0.41 & \\
\hline & & & $\mathrm{R}^{2}$ - Overall & 0.45 & \\
\hline & & & Breusch Pagan $\chi^{2}$ & 205.59 & \\
\hline & & & No. of Observations & 260 & \\
\hline
\end{tabular}

Note: *statistically significant at 1 percent

${ }^{* *}$ statistically significant at 5 percent

${ }^{* * *}$ statistically significant at 10 percent

Table 5: Regression Results

risks. In other words, regulating the market forces to stabilize firms' performance may not necessarily enhance their innovative efforts as R\&D itself is a risky proposition. Rather, under risky business conditions the firms may use alternative strategic options to improve their financial performance.

\section{Concluding Remarks}

In the context of recent amendments to the Indian Patent Act and introduction of product patent, the present paper attempts to examine the innovative efforts of Indian pharmaceutical companies in the new patent regime. The paper finds that although R\&D intensity has increased significantly in the current decade, the increasing R\&D efforts are not widespread across the firms and more than half of the Indian pharmaceutical companies do not spend at all on R\&D. This means that protection of intellectual property alone is not enough to encourage the firms towards innovation. An investigation into the determinant of innovative efforts suggests that, $R \& D$ intensity of the firms depends directly on their market size, capital intensity, exports orientation and past profitability, but inversely on their market share, selling efforts and import intensity. However, a firm's involvement in mergers and acquisition or sourcing of technology from foreign sources or variability in financial performance does not have any significant impact on its $R \& D$ efforts.

The findings of the present paper have three important policy implications. First, as R\&D efforts of the firms decline with increase in market share, it is necessary to control for the emergence of monopoly power in the market. Increasing market share and hence control over the market makes a firm complacent towards innovation. This means that inducing greater competition in the market is very important to induce the firms towards inhouse R\&D. It should be ensured that the incumbents don't create strategic barriers through their selling efforts to restrict entry of new firms and thereby to protect their market power. The competition authority should play a proactive role in this regard, particularly in controlling restrictive and unfair business practices by the incumbents. 
Second, greater penetration in the exports market encourages a firm towards innovation. This is very important for the firm to face the threat of international competition and survive in the global market in the long run. Hence, trade policies should be directed towards greater exports by the pharmaceutical firms. This requires the removal/relaxation of the restrictions on exports of pharmaceutical products and an appropriate incentive structure that can encourage the firms to penetrate in the international market in a bigger way. However, it should be ensured that greater exports don't limit the availability of essential drugs and other pharmaceutical products and increase their prices in the domestic market.

Third, the approach towards imports requires serious scrutiny. The policies relating to imports should provide easy access to necessary machinery and equipment. This is very important as easy access to such machinery and equipmens and hence greater capital base for a firm can have significant positive influence on its R\&D efforts. Further, easy imports of final drugs not only discourage firms from innovating, but also raise dependence on foreign firms for many life-saving medicines and hence may go against the interest of the common mass. It is, therefore, necessary to create an appropriate incentive/disincentive structure that discourages imports and motivates the firms to invest in the innovation of these important drugs. $[$.

\section{Reference:}

Audretsch, D. B., (1995), "Firm Profitability, Growth and Innovation", Review of Industrial Organization, Vol.10, No.5, pp. 579-588.

Bain, J. S. (1959), "Industrial Organisation", Wiley, New York.

Basant, R., (1997), “Technology Strategies of Large Enterprises in Indian Industry: Some

Explorations", World Development, Vol.25, No.10, pp.1683-1700.

Braga, H. and Willmore, L., (1991), "Technological Imports and Technological Effort: An

Analysis of their Determinants in Brazilian Firms", The Journal of Industrial Economics,

Vol. 39, No. 4, pp. 421-432.

Bhattacharya, M. and Bloch, H., (2004), "Determinants of Innovation", Small Business Economics, Vol. 22, No.2, pp. 155-162.

Branch, B., (1974), "Research and Development Activity and Profitability: A Distributed Lag Analysis", Journal of Political Economy, Vol.82, No.5, pp. 999-1011.

Breusch, T. S. and Pagan, A. R., (1980), "The Lagrange Multiplier Test and its Applications to Model Specifications in Econometrics", Review of Economic Studies, Vol.47, No.146, pp. 239-253.

Chaudhuri, S., (2007), "Is Product Patent Protection Necessary in Developing Countries for Innovation? R\&D by Indian Pharmaceutical Companies after TRIPS", Working Paper Series WPS No. 614/ September, Indian Institute of Management, Calcutta.
Davies, S., Lyons, B., Dixon, H., and Geroski, P., (1989), "Surveys in Economics: Economics of Industrial Organisation", Longman, London.

Doms, M., Dunne, T., and Roberts, M. J., (1995), "The Role of Technology Use in the Survival and Growth of Manufacturing Plants", International Journal of Industrial Organization, Vol.13, No.4, pp. 523-542.

Gilbert, R. and Newbery, D., (1982), "Preemptive Patenting and the Persistence of Monopoly", American Economic Review, Vol.72, pp.514526.

Grabowski, H. G., (1968), "The Determinants of Industrial Research and Development: A Study of the Chemical, Drug and Petroleum Industries", Journal of Political Economy, Vol. 76, pp. 527-547.

Greer, D. F. (1973), "The Case against Patent Systems in LessDeveloped Countries", The Journal of International Law and Economics, Vol.8, No.2, pp.223-266.

Gujarati, D. N. and Sangeetha, (2007), "Basic Econometrics", (Fourth Edition) (New Delhi: McGraw-Hill, Inc).

Hall, B. H., (1987), "The Relationship between Firm Size and Firm Growth in the US Manufacturing Sector", Journal of Industrial Economics, Vol. 35, No. 4, pp.583-606.

Horowitz, I., 1961, "Estimating Changes in the Research Budget", The Journal of Industrial Engineering, Vol. 3, No. 12, pp. 114-118

Janodia, M. D., Rao, J. V., Pandey, S., Sreedhar, D., Ligade, V. S., and Udupa, N. (2009), "Impact of Patents on Indian Pharma Industry's Growth and Competency: A Viewpoint of Pharmaceutical Companies in India", Journal of Intellectual Property Rights, Vol.14, No.5, pp. 432-36.

Kambhampati, U. S., (1996), "Industrial Concentration and Performance; A Study of the Structure, Conduct and Performance of Indian Industry", (New Delhi: Oxford University Press).

Katrak, H., (1990), "Imports of Technology and the Technological Efforts of Indian Enterprises, World Development, Vol. 18, No. 3, pp. 371381.

Katrak, H., (1991), "In House Technological Efforts, Imports of Technology and Enterprise Characteristics in Newly Industrializing Countries: The Indian Experience", Journal of International Development, Vol. 3, pp. 263-276.

Katrak, H., (1997), "Developing countries' imports of technology, inhouse technological capabilities and efforts: an analysis of the Indian experience", Journal of Development Economics, Vol.53, pp. 67-83.

Kiran, R. and Mishra, S., (2009), "Performance of the Indian Pharmaceutical Industry in Post- TRIPS Period: A Firm Level Analysis", International Review of Business Research Papers, Vol. 5, No.6, pp.148-160.

Kumar, N., (1987), "Technology Import and Local Research and Development in Indian Manufacturing", The Developing Economies, Vol.25, No.3, pp. 220-233.

Kumar, N. and Saqib, M., (1996), 'Firm Size, Opportunities for Adaptation, and In-house R\&D Activity in Developing Countries: The Case of Indian Manufacturing', Research Policy, 25(5), pp. 712-22.

Kumar, N. and Agarwal, A., (2000), "Liberalization, Outward Orientation and In-house R\&D Activity of Multinational and Local Firms: A Quantitative Exploration for Indian Manufacturing", Discussion Paper No. 07/20002, Research and Information System for the Non-Aligned and Other Developing Countries, New Delhi..

Kuznets, S., (1962), "Inventive Activity: Problems of Definition and Measurement" in N.B.E.T. (ed.), The Rate and Direction of Inventive Activity, (Princeton: Princeton University Press)

Lall, S., (1983), "Determinants of R\&D in an LDC: The Indian Engineering Industry", Economic Letters, Vol. 37, No. 3, pp.379-383.

Mani, S., (2009), 'Is India Becoming More Innovative Since 1991?' Economic and Political Weekly, Vol.44, No.46, pp. 41-51. 
Mason, E. S., (1939), “Price and Production Policies of Large Scale Enterprises", American Economic Review Supplement, Vol.29, No.1, pp. 6174.

Mishra, P., (2006), "Mergers Acquisition Market Structure and Industry Performance: Experience of Indian Pharmaceutical Industry", Review of Development and Change, Vol.11, No.2, pp. 135-164.

Mishra, P. and Chandra, T., (2010), "Mergers, Acquisitions and Firms' Performance: Experience of Indian Pharmaceutical Industry", Eurasian Journal of Business and Economics, Vol. 3, No. 5, 111-126.

Penrose, E. T., (1951), "The Economics of the International Patent System", (Baltimore: The Johns Hopkins University Press).

Pradhan, J. P., (2003), "Liberalization, Firm Size and R\&D Performance: A Firm Level Study of the Indian Pharmaceutical Industry", Discussion Paper No. 40/2003, Research and Information System for the Non-Aligned and Other Developing Countries, New Delhi.

Scherer, F., (1967), "Market Structure and the Employment of Scientists and Engineers", American Econiomic Review, Vol. 57, pp. 524-531.

Scherer, F.M. and Ross, D., (1990), "Industrial Market Structure and Economic Performance", (Chicago: Rand Mcnally).

Siddharthan, N.S. and Krishna, K.L., 1994, "Determinants of Technology Imports: Evidence for Indian Firms", Working Paper Series No. E/161/94, Institute of Economic Growth, New Delhi.

Siebeck, Wolfgang E. (ed.) (1990), "Strengthening Protection of Intellectual Property in developing Countries: A Survey of the Literature." World Bank Discussion Paper, World Bank, Washington DC.

Ray, A. S., (2008), "Learning and Innovation in the Indian Pharmaceutical Industry: The Role of IPR and other Policy Interventions", Electronic Journal of Communication, Information \& Innovation in Health, Vol. 2, No. 2, pp. 71-77.

Vaitsos, C., (1972), "Patents Revisited: Their Functioning in Developing Countries", Journal of Development Studies, Vol.9, No.1, pp. 71-97.

\section{Appendix I: Measurement of the Variables}

As mentioned earlier, all the variables are measured as simple three year averages from the year under reference to make the data set more consistent over time, along with taking care of the adjustment process and eliminating the problem of simultaneity amongst the variables.

RD: The ratio of research and development related expenditure (R) by a firm to its sales $(S)$ is used as a measure of research and development intensity (RD) of that firm, i.e., $R D_{i t}=\frac{\frac{R E_{i t}}{S_{i t}}+\frac{R E_{i, t-1}}{S_{i, t-1}}+\frac{R E_{i, t-2}}{S_{i, t-2}}}{3}$

MSZ: The variable market size (MSZ) of a firm is measured as,

$$
M S Z_{i t}=\frac{\ln \left(S_{i t}\right)+\ln \left(S_{i, t-1}\right)+\ln \left(S_{i, t-2}\right)}{3}
$$

where, $S_{i t}$ stands for sales of firm i in year $t$.

SHARE: Market share of a firm (SHARE) is measured by using the following formula:

$$
\text { SHARE }_{i t}=\frac{\frac{S_{i t}}{\sum_{i=1}^{n} S_{i t}}+\frac{S_{i, t-1}}{\sum_{i=1}^{n} S_{i, t-1}}+\frac{S_{i, t-2}}{\sum_{i=1}^{n} S_{i, t-2}}}{3}
$$

Here, $\mathrm{S}_{\mathrm{it}}$ stands for sales of firm $\mathrm{i}$ in year $\mathrm{t}$ and $\mathrm{n}$ for total number of firms in the industry.

MA: The total number of deals during last three years is considered as a measure of mergers and acquisitions (MA) in year t, i.e.,

$$
M A_{i t}=M A_{i t}+M A_{i, t-1}+M A_{i, t-2}
$$

KI: The ratio of capital employed (CE) by a firm to its sales $(\mathrm{S})$ is used as a measure of its capital intensity (KI), i.e.,

$$
K I_{i t}=\frac{\frac{C E_{i t}}{S_{i t}}+\frac{C E_{i, t-1}}{S_{i, t-1}}+\frac{C E_{i, t-2}}{S_{i, t-2}}}{3}
$$


SELL: Selling intensity (SELL) of a firm is measured by using the following formula:

$S E L L_{i t}=\frac{\frac{S E_{i t}}{S_{i t}}+\frac{S E_{i, t-1}}{S_{i, t-1}}+\frac{S E_{i, t-2}}{S_{i, t-2}}}{3}$

Here, $\mathrm{SE}_{\mathrm{it}}$ and $\mathrm{S}_{\mathrm{it}}$ stand for total selling expenses (i.e., the sum of advertising, marketing and distribution related expenses) and sales respectively of firm i in year $t$.

FTP: The present paper uses the ratio of expenditure for foreign technology (FT) by a firm to its sales (S) as a measure of foreign technology purchase intensity (FTP) of that firm, i.e.,

$F T P_{i t}=\frac{\frac{F T_{i t}}{S_{i t}}+\frac{F T_{i, t-1}}{S_{i, t-1}}+\frac{F T_{i, t-2}}{S_{i, t-2}}}{3}$

EXP: We measure exports intensity (EXP) of a firm by using the following formula:

$E X P_{i t}=\frac{\frac{E X_{i t}}{S_{i t}}+\frac{E X_{i, t-1}}{S_{i, t-1}}+\frac{E X_{i, t-2}}{S_{i, t-2}}}{3}$

Here, $E X_{i t}$ and $S_{i t}$ stand for exports and sales respectively of firm i in year $t$.

IMP: Imports intensity (IMP) of a firm is measured by using the following formula:

$I M P_{i t}=\frac{\frac{I M_{i t}}{S_{i t}}+\frac{I M_{i, t-1}}{S_{i, t-1}}+\frac{I M_{i, t-2}}{S_{i, t-2}}}{3}$

Here, $I M_{i t}$ and $S_{i t}$ stand for imports and sales respectively of firm i in year $t$.

PROF: The ratio of profit before interest and tax (PBIT) to sales (S) is used as the first measure of profitability (PROF1), i.e.

PROF $_{i t}=\frac{\frac{P B I T_{i t}}{S_{i t}}+\frac{P B I T_{i, t-1}}{S_{i, t-1}}+\frac{P B I T_{i, t-2}}{S_{i, t-2}}}{3}$

FR: The present paper uses variability of profitability of a firm as a measure of its risks of operation over last three years, i.e.,

$F R_{i t}=\sigma\left(\frac{P B I T_{i t}}{S_{i t}}, \frac{P B I T_{i, t-1}}{S_{i, t-1}}, \frac{P B I T_{i, t-2}}{S_{i, t-2}}\right)$ 